\title{
Soil macrofauna communities in mountain forests of Ngoc Linh Nature Reserve (Vietnam, Kon Tum province)
}

\section{Сообщества почвенной мезофауны горных месов заповедника Нгок Аинь (Вьетнам, провинция Кон Тум)}

\author{
A.E. Anichkin ${ }^{1,2}$, Nguyen Van Thinh ${ }^{2}$ \\ А.Е. Аничкин, Нгуен Ван Тхинь
}

\footnotetext{
${ }^{1}$ A.N. Severtsov Institute of Ecology and Evolution, Russian Academy of Sciences, Leninsky pr. 33, Moscow, 119071 Russia

${ }^{1}$ Институт проблем экологии и эволюции им. А.Н. Северцова РАН, 119071, Москва, Ленинский проспект, 33

${ }^{2}$ Joint Russian-Vietnamese Research and Technological Center, Ho Chi Minh City, Vietnam

e-mail: anisoil@mail.ru

${ }^{2}$ Российско-Вьетнамский Тропический научно-исследовательский и технологический центр, Вьетнам, Хошимин.
}

KEY WORDS: soil invertebrates, mountain tropical forests, coniferous forests, peat soils, South-East Asia, Vietnam.

КЛЮЧЕВЫЕ СЛОВА: почвенные беспозвоночные, горные тропические леса, хвойные леса, торфяные почвы, Юго-Восточная Азия, Вьетнам.

ABSTRACT: The density, biomass and taxonomic composition of soil macrofauna were studied in seven sites at different altitude (from $1600 \mathrm{~m}$ to $2370 \mathrm{~m}$ a.s.l.), differing in plant community composition, edaphic and climatic conditions. Soil macrofauna had high taxonomic diversity (more than 570 species), density (up to 1700 ind $\mathrm{m}^{-2}$ ) and biomass (up to $41 \mathrm{~g} \mathrm{~m}^{-2}$ ). These values are much greater than previously published data on the density, diversity and biomass of soil macrofauna in mountain ecosystems of South-East Asia. Detritivores dominated at all sites studied, but their biomass was considerably reduced at sites with peat soils, indicating smaller participation in the decomposition process. Clear differences in the composition of local macrofauna communities were revealed. Factors determining the density of soil and litter-dwelling invertebrates in montane ecosystems studied are discussed.

РЕЗЮМЕ: Исследованы показатели численности и биомассы почвенных беспозвоночных на семи площадках, различающихся по лесорастительным и почвенным условиям и расположенных на высотах от 1600 м до 2370 м. н.у.м. Почвенная и подстилочная фауна в исследованных растительных формациях наряду с высоким таксономическим разнообразием (более 570 видов), характеризовалась высокой численностью (до 1700 экз./ ${ }^{2}$ ) и биомассой (до 41 г/м²), что превышает литературные данные по обилию мезофауны горных экосистемах ЮгоВосточной Азии. Сапрофаги доминировали по численности и обилию, однако на площадках с торфяными почвами их биомасса была значительно ниже,

Dedicated to Prof. Bella R. Striganova on the occasion of her 80th anniversary. что указывает на их меньшую роль в процессах трансформации органического вещества. Выявлены четкие отличия в структуре доминирования локальных комплексов почвенных беспозвоночных. Высказаны предположения о природе факторов, определяющих общее обилие почвенной и подстилочной мезофауны в исследованных экосистемах.

\section{Introduction}

Investigations of mountain ecosystems provide an excellent tool for understanding of functioning of biogeocenoses, but there are only a few studies devoted to soil animal communities of mountain forests of SouthEast Asia. Fairly detailed studies have been performed in the states of Sarawak and Sabah of Malaysia [Collins, 1980; Leakey, Proctor, 1987]. However, these regions lie closer to the equator. The purpose of this study was to provide a quantitative description of soil macrofauna in different forest formations at a range of altitudes at the Mount Ngoc Linh in the Central Highlands of Vietnam.

Mount Ngoc Linh $\left(15^{\circ} 05^{\prime} \mathrm{N}, 107^{\circ} 57^{\prime} \mathrm{E}\right.$, ca. $2598 \mathrm{~m}$ a.s.1.) is the highest peak in the Ngok Linh Nature Reserve located within Dac Glei and Dac To districts in the mountainous north of Kon Tum province. The Ngoc Linh Nature Reserve enjoys a humid tropic climate; however, the climate varies considerably with altitude. In Dac To and Con Tum at altitudes of 650 and $536 \mathrm{~m}$ a.s.1., the average yearly temperature is 22 and $23^{\circ} \mathrm{C}$, respectively. Total annual rainfall and number of rainy days increase with altitude with maximum values on Ngoc Linh summit ( $4000 \mathrm{~mm}, 250$ rainy days per annum). The rainy season starts in May and lasts 
until the end of October. The main forest types of nature reserve are lowland and montane evergreen forests.

\section{Material and methods}

Studies were conducted from March 19 to April 9 2006. Soil animal communities were studied at seven sites, at altitudes ranging from 1600 to $2370 \mathrm{~m}$ a.s.1.:

1. Deciduous forest at $1600 \mathrm{~m}$ a.s.1. (D-1600). The relief flat, undulating, forest stand well developed. The overstory consisted of Fagaceae and Betulaceae. The upper litter layer (L) consisted mainly of leaves (about $0.5 \mathrm{~cm}$ thick). The $\mathrm{F}$ and $\mathrm{H}$ horizons of litter were absent. The soil was dark loamy with a poorly developed profile. The A horizon (topsoil) was less than 2 $\mathrm{cm}$ thick. During sampling, mean soil temperature at a depth of $10 \mathrm{~cm}$ was $19.4^{\circ} \mathrm{C}$, mean $\mathrm{pH}$ of soil 6.6.

2. Deciduous forest at $1800 \mathrm{~m}$ a.s.l. (D-1800). The relief undulating, gently sloping northeastward, forest stand well developed. The overstory consisted of Fagaceae and Aceraceae. The L horizon of litter consisted mainly of leaves, calybia and cupules of Castanopsis sp., $\mathrm{F}$ and $\mathrm{H}$ horizons were absent. The soil was dark loamy with well-developed humus horizon (4-10 $\mathrm{cm}$ thick), B horizon dark yellow with a high proportion of sand. Mean soil temperature at a depth of $10 \mathrm{~cm}$ was on average $17.7^{\circ} \mathrm{C}$, mean soil $\mathrm{pH} 6.5$.

3. Coniferous forest at $2000 \mathrm{~m}$ a.s.1. (C-2000). The relief undulating, gently sloping southwestward. The overstory at this site consisted of Pinus dalatensis. The L horizon consisted mainly of pine branches, needles and cones $(0.5-1 \mathrm{~cm}$ thick). Well developed $\mathrm{F}+\mathrm{H}$ horizon (4-5 cm thick) consisted of decomposing plant materials with roots and fungal hyphae. Underlying organic layer (peat) reached $40 \mathrm{~cm}$ in soil with a thickness. It rested on the mineral horizon formed by yellow sandy soil (E horizon) or on the thick tree roots. Mean soil temperature at a depth of $10 \mathrm{~cm}$ was $15.5^{\circ} \mathrm{C}$. The mean $\mathrm{pH}$ of peat soil was 4.0, of E horizon - 6.6.

4. Deciduous forest at $2150 \mathrm{~m}$ a.s.1. (D-2150). The relief flat undulating. Tree stand well developed, the overstory consisted of Fagaceae. Herb layer well developed. Litter layer consisted of fresh litter, up to 1 $\mathrm{cm}$ thick. Soil have a high proportion of sand with well-developed profile. Topsoil $10 \mathrm{~cm}$ thick, gray; B horizon yellow. Mean soil temperature at a depth of 10 $\mathrm{cm}$ was $17.7^{\circ} \mathrm{C}$, mean $\mathrm{pH}$ of soil 6.5 .

5. Coniferous forest at $2340 \mathrm{~m}$ a.s.1. (C-2340). The site was situated on an undulating ridge sloping southeastward. The overstory consisted of Pinus dalatensis. The L horizon consisted mainly of pine branches, needles and cones (thickness $-0.5 \mathrm{~cm}$ ). FH horizon well developed (4-5 cm), consisted of decomposing plant materials with roots and fungal hyphae. The soil was peat soil with a thickness from 50 to $150 \mathrm{~cm}$ lying on yellow sandy mineral soil. Mean soil temperature at a depth of $10 \mathrm{~cm}$ was $13.9^{\circ} \mathrm{C}$; mean $\mathrm{pH}$ of peat soil 5.1 .

6. Deciduous forest at $2350 \mathrm{~m}$ a.s.1. (D-2350). The relief of this site was gently sloping southeastward.
Tree stand was well developed. The overstory consisted of Fagaceae, herb layer was developed. The L horizon consisted of leaves of deciduous trees ( $1 \mathrm{~cm}$ thick). The $\mathrm{F}$ and $\mathrm{H}$ horizons were absent. The soil was loamy with well developed profile. The A horizon was dark, up to $20 \mathrm{~cm}$ thick. The $\mathrm{B}$ horizon was yellow. Mean soil temperature at a depth of $10 \mathrm{~cm} 13.8^{\circ} \mathrm{C}$; mean pH 6.2.

7. Deciduous forest at $2370 \mathrm{~m}$ a.s.1. (R-2370). Site relief was flat, sloping southwestward. Trees were sparse, but the shrub layer well developed (Rhododendron sp.). The $\mathrm{L}$ horizon consisted of rhododendron leaves $(0.5-1 \mathrm{~cm}$ thick). The FH horizons well developed $(\mathrm{ca} .4 \mathrm{~cm})$. The soil was organic or peat soil with a thickness from $60 \mathrm{~cm}$ to $100 \mathrm{~cm}$. Mean soil temperature at a depth of $10 \mathrm{~cm}$ was $13.7^{\circ} \mathrm{C}$, mean $\mathrm{pH}$ of peat soil was 4.7.

Soil macrofauna (excluding termites and ants) was sampled by a modified hand-sorting method [Ghilarov et al., 1975; Anichkin 2011]. Samples of litter were collected using a stainless frame $(50 \times 50 \mathrm{~cm})$ and passed through a sifter (mesh size $2 \times 2 \mathrm{~cm}$ ). The coarse fraction was examined immediately; the fine fraction was placed in canvas bags and sorted at the camp. Soil samples were collected by a $25 \times 25 \mathrm{~cm}$ stainless frame and sorted generally in the field. The upper soil layer $(0-2 \mathrm{~cm})$ containing many small invertebrates was sieved through a column of sieves with mesh sizes of 10, 7, 5, 3 and $2 \mathrm{~mm}$. The underlying soil was separated to 2-10, 10-20, 20-30 cm layers. Four or eight soil and litter samples were taken from each site during the expedition. All specimens of invertebrates (more than 4500 ind. in total) were identified to the level of order or family and preserved in $80 \%$ alcohol. Wet weight (to the nearest $0.1 \mathrm{mg}$ ) was estimated in alcohol-preserved animals.

In tables and figures, data on the density and biomass of soil invertebrates are shown as mean per square meter. All statistical calculations were performed in $\mathrm{R}$ (R Core Development Team, 2009).

\section{Results and discussion}

Density and biomass of soil and litter macrofauna. The total density of invertebrates varied from 821.5 to 1701.5 ind. $\mathrm{m}^{-2}$ (Table 1; Fig. 1a). The greatest abundance of soil animals was observed in litter and soil of sites situated above $2300 \mathrm{~m}$ a.s.l., with the maximum density in deciduous forest at $2350 \mathrm{~m}$ a.s.1. The smallest number of invertebrates was observed in deciduous forests at 1800 and $2150 \mathrm{~m}$ a.s.1. (821.5 and 965.0 ind $\mathrm{m}^{-2}$ ). There was no direct connection between total density of soil macrofauna and type of the forest (deciduous or coniferous) or soil conditions (peat or mineral soil). The total biomass of soil macrofauna ranged from $8.1 \mathrm{~g} \mathrm{~m}^{-2}$ (C-2300) to $41 \mathrm{~g} \mathrm{~m}^{-2}$ (D-2350). The greatest biomass was found in deciduous forests (Fig. 1b); the smallest - in the coniferous forests and in the deciduous forest with a dominance of rhododendron at $2370 \mathrm{~m}$ a.s.l. (R-2370), i.e. in the peat soils, due to the 


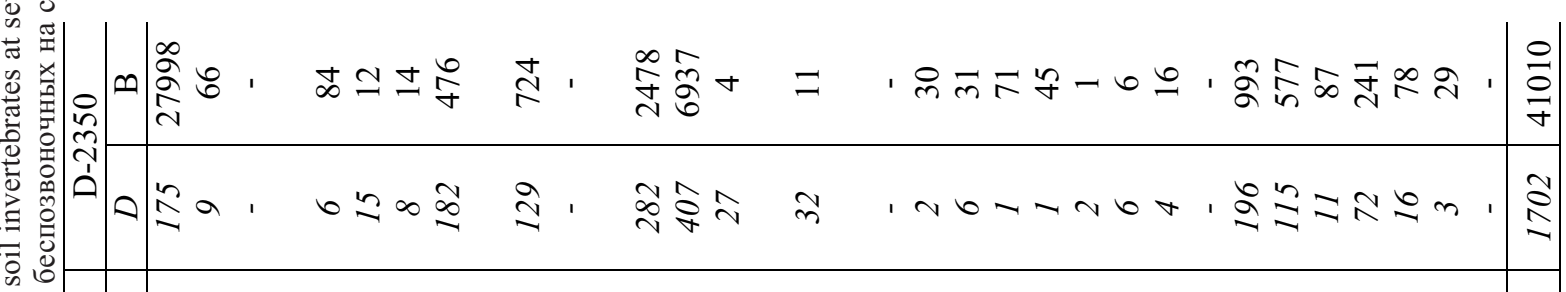

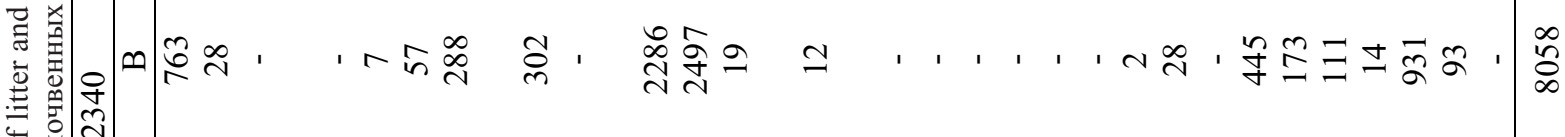

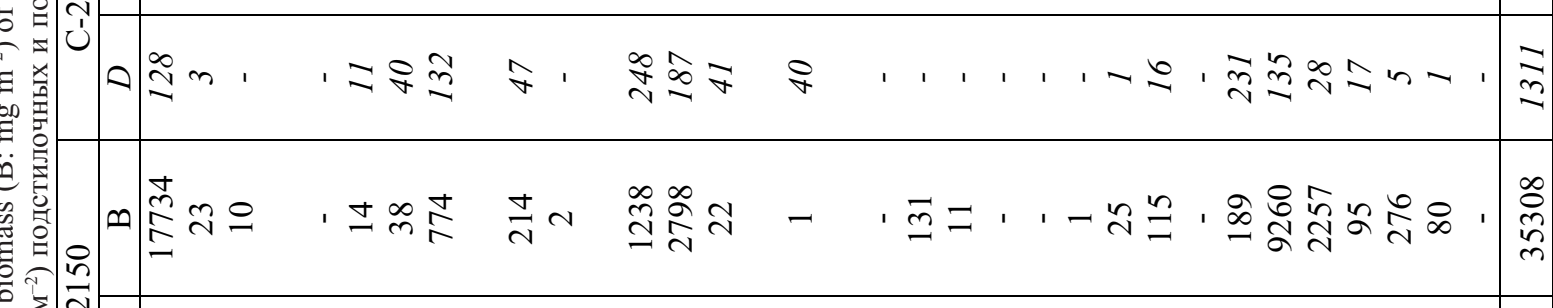

远

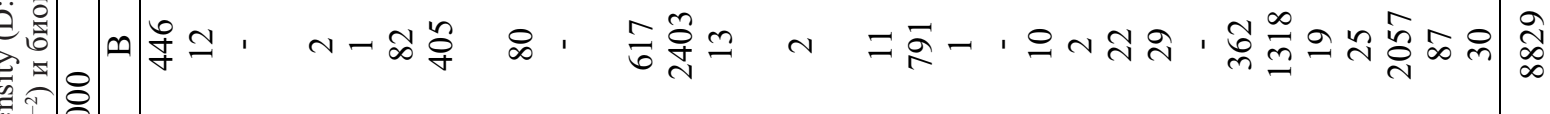

-

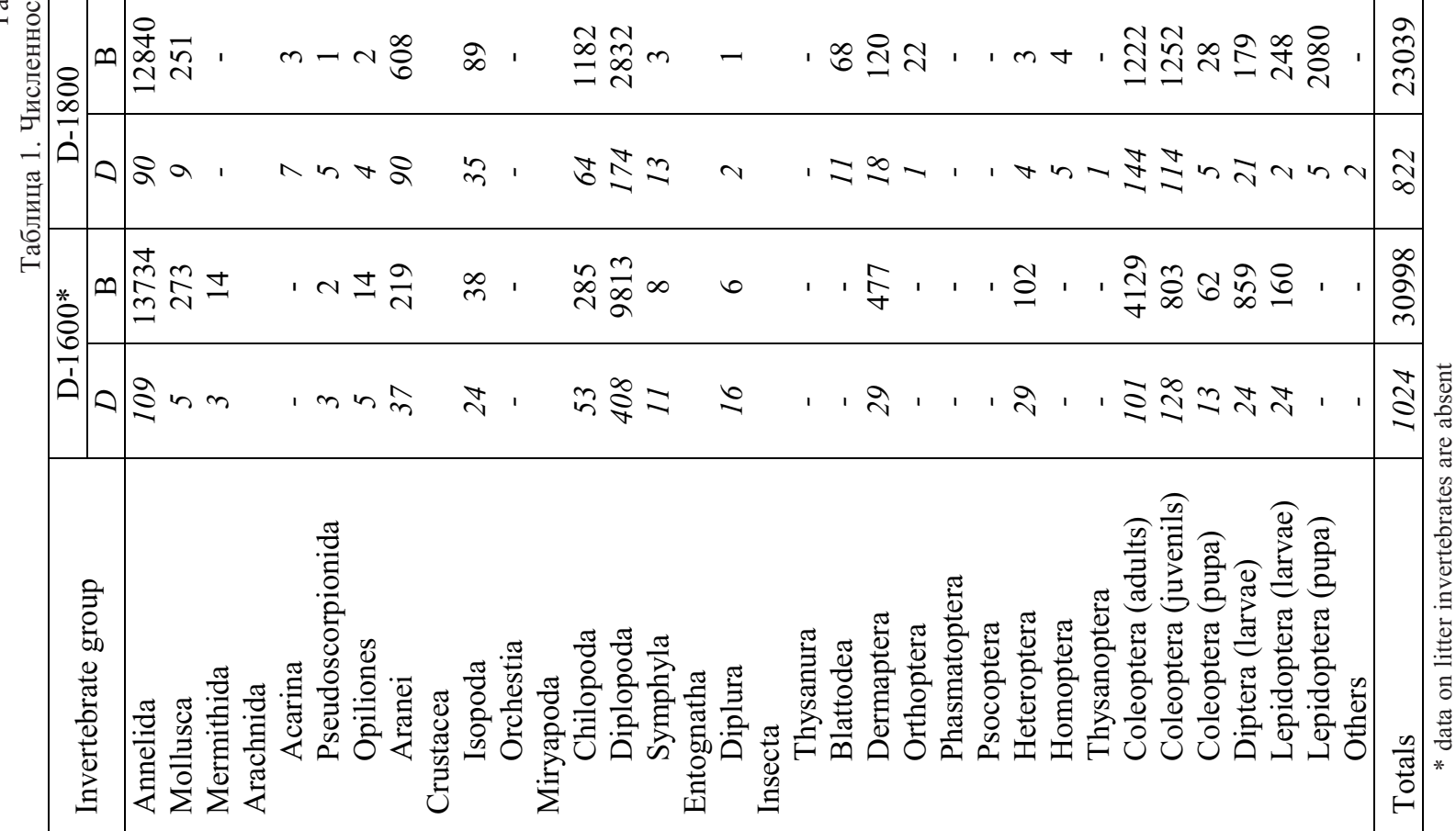



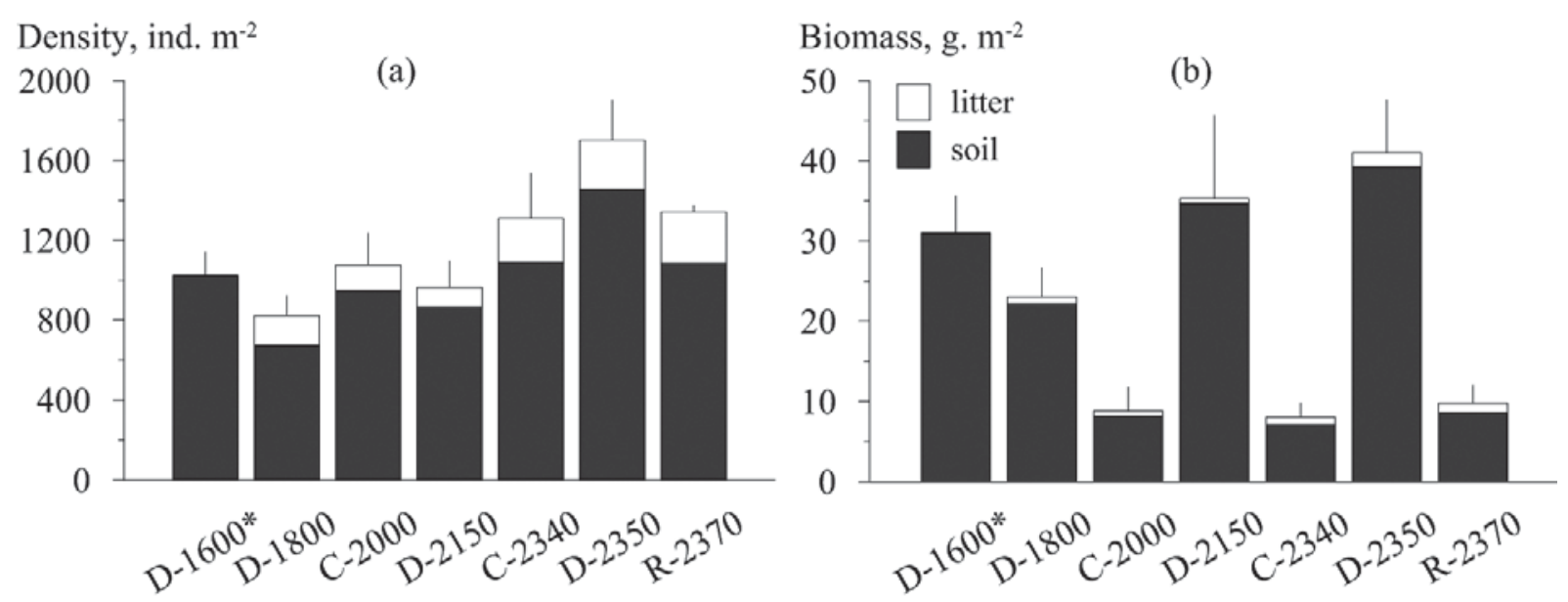

Fig. 1. The density (a) and biomass (b) of sol invertebrates at seven sites. Error bars indicate standard error of mean. Рис. 1. Численность (а) и биомасса (б) почвенных беспозвоночных на семи площадках.
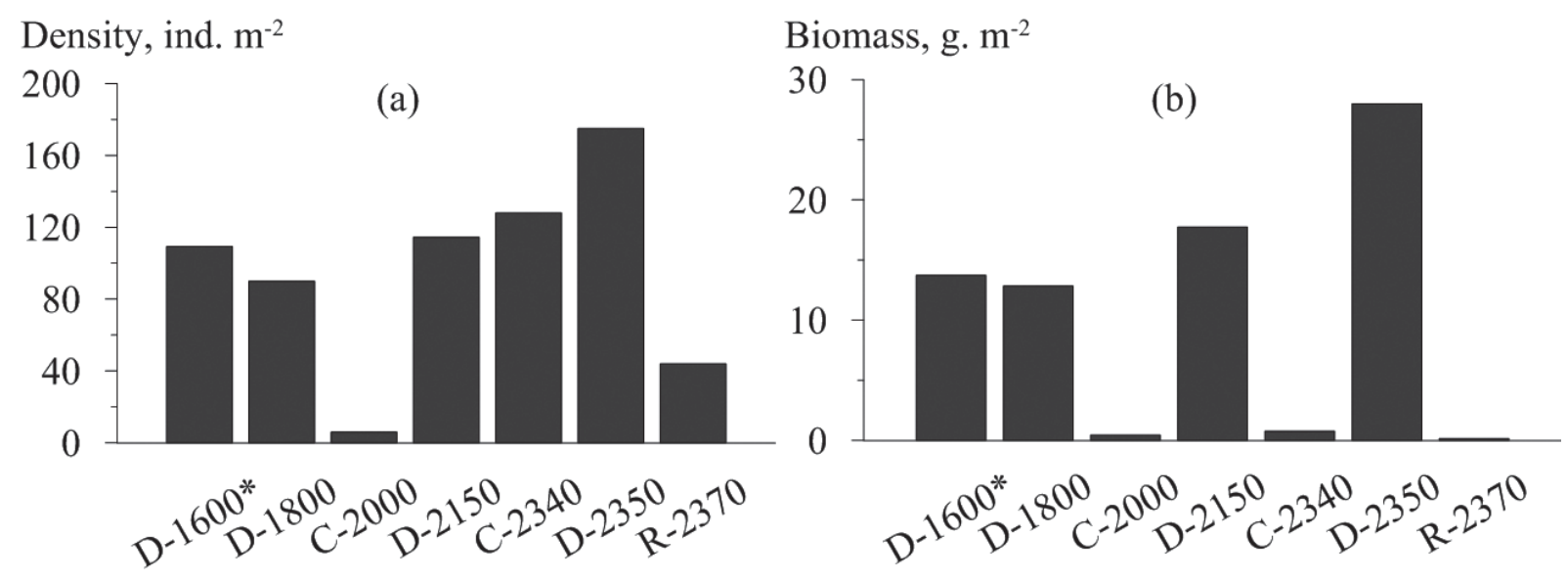

Fig. 2. The density (a) and biomass (b) of the earthworms. Рис.2. Численность (а) и биомасса (b) червей.

very low biomass of endogeic invertebrates. The biomass of litter invertebrates was highest at the sites located higher than $2300 \mathrm{~m}$ a.s.l.

Maximum values of total density and biomass of soil invertebrates in studied sites are markedly greater than in the mountain forest ecosystems of the region reported in previous studies [Collins, 1980; Krivolutskii et al., 1997; Anichkin, 2007]. For example, the density of soil animals (excluding ants and termites) in forests at altitudes ranging from 800 to $2376 \mathrm{~m}$ a.s.l. varied from 127 to 613 ind. $\mathrm{m}^{-2}$ and biomass did not exceed $19 \mathrm{~g} \mathrm{~m}^{-2}$ [Collins, 1980].

Data on the total density and biomass of soil invertebrates do not reflect peculiarities of soil macrofauna communities in different types of investigated mountain forests. Therefore, the distribution of main taxonomic groups of soil macrofauna is examined below.

Annelida. The density of Oligochaeta varied from 6 to 175 ind. $\mathrm{m}^{-2}$ (Fig. 2); they were represented mainly by endogeic earthworms. The finding of earthworms in litter layer was sporadic in spite of its high moisture

content. Earthworms could not be identified to species level, however the average- and big-sized species of suborder Lumbricina (megadrile) were found exclusively in deciduous forests. Only one specimen of megadrile was registered in coniferous forest (C-2000) in mineral soil $(\mathrm{pH}=6.6)$ under the peat layer $(\mathrm{pH}=4.0)$. The microdrile (small-sized oligochaets) of family Enchytraeidae were found in peat soils of coniferous forest at $2350 \mathrm{~m}$ a.s.1. and the deciduous forest with rhododendron. This distribution of Oligochaeta is likely connected with the sensitivity of Lumbricina to soil acidity [Edwards, Bohlen, 1996]. Enchytraeidae are much more tolerant to low $\mathrm{pH}$ values, which makes them an important agent in the transformation plant remains in acid peat soils [Kozlovskaya, 1976; Persson et al., 1980; Huhta et al., 1986].

Arachnida. The total density of arachnids fluctuated from 104 to 230 ind. $\mathrm{m}^{-2}$ with biomass ranging from 0.2 to $1.2 \mathrm{~g} \mathrm{~m}^{-2}$ (Fig. 3). The maximum density and biomass of Arachnida were observed in deciduous forest at $2370 \mathrm{~m}$ a.s.1. The abundance of spiders and 
Density, ind. $\mathrm{m}^{-2}$

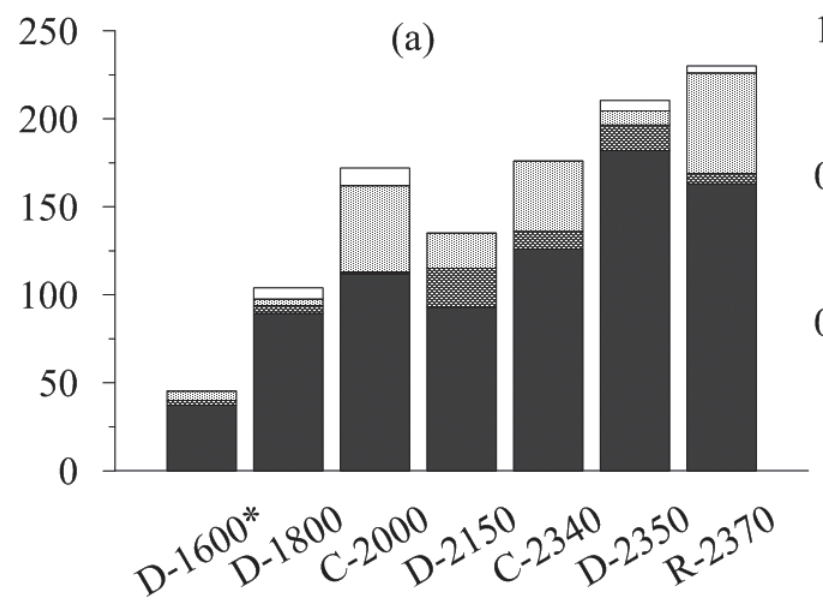

Biomass, $\mathrm{g} \mathrm{m}^{-2}$

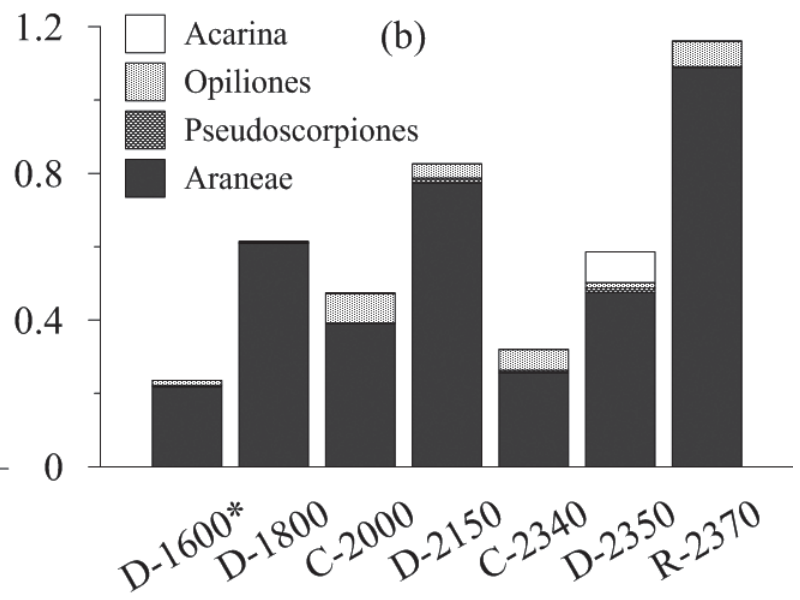

Fig. 3. The density (a) and biomass (b) of arachnids.

Рис. 3 Численность (a) и биомасса (b) паукообразных.

Table 2. The density (ind. $\left.\mathrm{m}^{-2}\right)$ and percentage ( $\%$ of total density, in brackets) of spiders. Таблица 2. Численность (экз. $\mathrm{M}^{-2}$ ) и процентное соотношение пауков.

\begin{tabular}{|l|c|c|c|c|c|c|c|}
\hline Families & D-1600* & D-1800 & C-2000 & D-2150 & C-2340 & D-2350 & R-2370 \\
\hline Dipluridae & - & $2(2)$ & $4(4)$ & $2(2)$ & - & $2(1)$ & $4(2)$ \\
Tetrablemmidae & - & $4(4)$ & - & - & - & - & - \\
Pholcidae & - & - & - & - & - & $2(1)$ & - \\
Oonopidae & - & $24(27)$ & $36(32)$ & $20.5(22)$ & $13(10)$ & $8(4)$ & $24(15)$ \\
Theridiidae & $2.7(7)$ & $0.5(1)$ & $0.5(0)$ & - & - & $5.5(3)$ & $4(2)$ \\
Linyphiidae & $8(21)$ & $21.5(24)$ & $25(22)$ & $7(8)$ & $4(3)$ & $57.5(32)$ & $81(50)$ \\
Hahniidae & - & - & - & $0.5(1)$ & - & $29.5(16)$ & - \\
Agelenidae & $18.7(50)$ & $17.5(20)$ & $16.5(15)$ & $33(35)$ & $53(42)$ & $58.5(32)$ & $12(7)$ \\
Liocranidae & - & $2.5(3)$ & $10.5(9)$ & $16(17)$ & $3(2)$ & $7.5(4)$ & $7(4)$ \\
Clubionidae & - & $0.5(1)$ & $4(4)$ & - & $8(6)$ & $1(1)$ & - \\
Zodariidae & - & $6.5(7)$ & $1(1)$ & $2.5(3)$ & $4(3)$ & $3(2)$ & $8(5)$ \\
Gnaphosidae & $2.7(7)$ & - & - & $2(2)$ & - & - & - \\
Sparassidae & $2.7(7)$ & $2.5(3)$ & $0.5(0)$ & $2.5(3)$ & $1(1)$ & $0.5(0)$ & $13(8)$ \\
Salticidae & - & $4(4)$ & $1.5(1)$ & $3(3)$ & - & $6(3)$ & $1(1)$ \\
Others (juveniles) & $2.7(7)$ & $4(4)$ & $12.5(11)$ & $4(4)$ & $40(32)$ & $1(1)$ & $9(6)$ \\
\hline Total & 37.3 & 89.5 & 112 & 93 & 126 & 182 & 163 \\
\hline
\end{tabular}

harvestmen (mainly of Laniatores) in coniferous forests was high, but their total biomass was low, due to peculiar community structure of spiders (Table 2). Of 14 families of spiders recorded, the most numerous were Agelenidae, Oonopidae and Linyphiidae. The density of the most numerous in the lowland forests of South Vietnam spiders of Zodariidae [Anichkin, 2007] did not exceed 7 ind. $\mathrm{m}^{-2}$ at the investigated sites, whereas widespread spiders of Ctenidae, Corniidae and Scytodidae families were not found at all. At the same time the density of Linyphiidae was high, especially in the deciduous forest at $2370 \mathrm{~m}$ a.s.l. The abundance of these spiders in deciduous forests studied correlated linearly with altitude. This pattern is likely typical for Linyphiidae; in particular, similar situation was described in the canopy spiders' fauna of mountain for- ests in Tanzania, where the importance of linyphiids increases with altitude [Sorensen, 2004]. Overall, the spider fauna of the investigated forests was very different from that in the lowland forests, but similar to spider communities in other mountain forests of South Vietnam [Anichkin, 2007].

Crustacea. Amphipoda were found only in the deciduous forest at $2150 \mathrm{~m}$ a.s.l. The abundance of Isopoda varied from 20 to 128 ind. $\mathrm{m}^{-2}$. The density of Isopoda correlated positively with altitude, both in mineral soils of deciduous forests and in organic soils of coniferous forests (including deciduous forest with rhododendron), though in peat soils their abundance was much lower (Fig. 4).

Myriapoda. This group formed a major element of the soil macrofauna. Their abundance varied from 250 
Density, ind. $\mathrm{m}^{-2}$

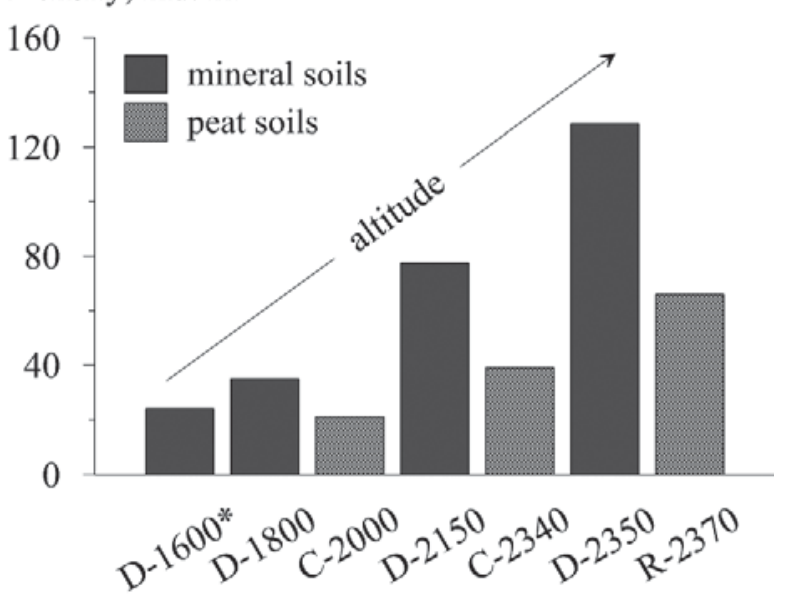

Fig. 4. The density of Isopoda.

Рис. 4. Численность мокриц. community structure of centipedes in the studied sites can be explained by differences in life forms or ecomorphs based on their morphological adaptations. Cryptopides having slender body and long legs are the typical litter or topsoil dwellers and belong to epigeobiont group of soil animals [Sharova, 1981]. Geophilid centipedes possess a thin serpentine body and shortened legs adapted for the dwelling in deeper soil horizons; they belong to the geobiont group. Peat soils with thick litter provide conditions for deeper penetration of epigeobiont animals. This was reflected in the decreased density of geophilids that were replaced by cryptopid centipedes. The change in the taxonomic structure of centipedes did not affect total biomass (Fig. 5b).

The density and biomass of Diplopoda reached more than 400 ind. $\mathrm{m}^{-2}$ and $9 \mathrm{~g} \mathrm{~m}^{-2}$, respectively (Table 3 ). The density of Julida was highest in deciduous forests except for the forest at $2150 \mathrm{~m}$ a.s.l. Polydesmida were represented by Fuhrmannodesmidae, Platyrhacidae,

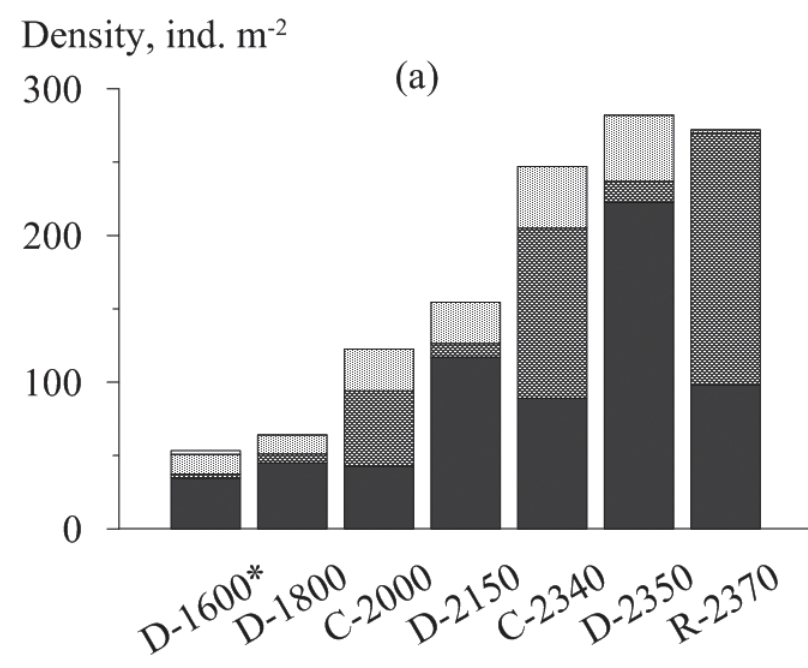

Biomass, $\mathrm{g} \mathrm{m}^{-2}$

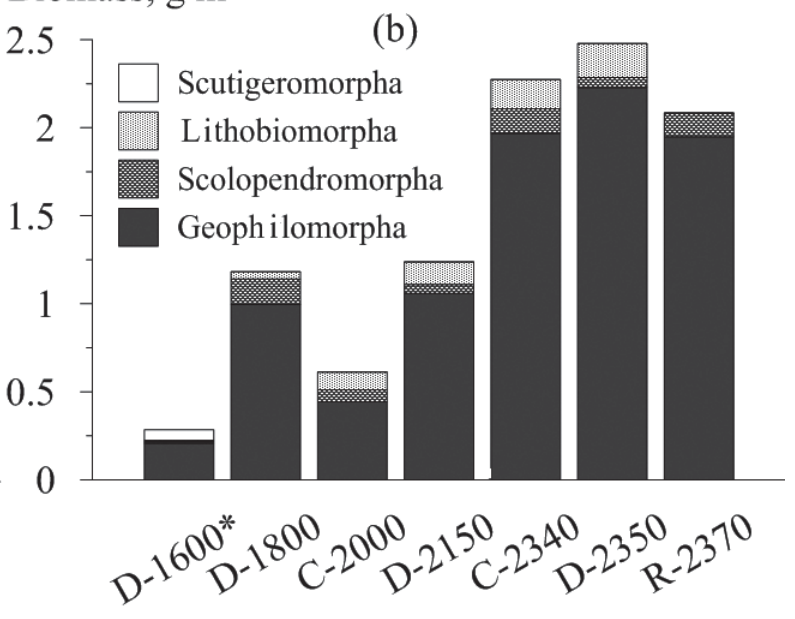

Fig. 5. The density (a) and biomass (b) of centipedes.

Рис. 5. Численность (а) и биомасса (b) хищных многоножек.

to 715 ind. $\mathrm{m}^{-2}$ (30-51\% of the total density of soil invertebrates), and biomass - from 3 to $10 \mathrm{~g} \mathrm{~m}^{-2}$ (up to $70 \%$ of total biomass at some sites). Myriapods were represented by predatory Chilopoda, and by detritivorous Diplopoda and Symphyla. The abundance of centipedes reached 272 ind. $\mathrm{m}^{-2}$ (Fig. 5a). Scutigeromorpha were found in deciduous forest at D-1600 $\mathrm{m}$ a.s.l. only. The density of Lithobiomorpha varied from 2 to 45 ind. $\mathrm{m}^{-2}$ with the highest values in the coniferous forest at $2340 \mathrm{~m}$ a.s.l. and deciduous forest at $2350 \mathrm{~m}$ a.s.l., and lowest value in the deciduous forest with rhododendron.

Scolopendromorpha and Geophilomorpha had the greatest density. The first order was represented mainly by Cryptopidae (from 3 to 172 ind. $\mathrm{m}^{-2}$ ) with greatest density in the peat soils. In contrast, the abundance of Geophylomorpha reached maximum values in the mineral soils (up to 223 ind. $\mathrm{m}^{-2}$ ). Differences in the
Pyrgodesmidae, Opisotretidae and Paradoxosomatidae. Two latter families were the most abundant. The density of Paradoxosomatidae was highest in mineral soils of deciduous forests especially in the soil of site D1600. In contrast, the density of Opisotretidae was highest in sites with peat soils.

Symphyla were present at all sites with high density in peat soils of coniferous forests; the highest abundance was found in the organic soil of deciduous forest at $2370 \mathrm{~m}$ a.s.l. (63 ind. $\mathrm{m}^{-2}$ ). In the mineral soils the abundance of Symphyla did not exceed 30 ind. $\mathrm{m}^{-2}$. This pattern is probably related to the high density of potential preys (small-sized arthropods, nematodes and annelids) for predatory or abundant fungal hyphae and root materials for omnivorous Symphyla in peat soils.

Insecta. Insects were the second most represented group of soil invertebrates ( $40 \%$ of total soil macrofau- 
Table 3. The total density (ind. $\mathrm{m}^{-2}$ ) and the percent relationship (in brackets) of millipede orders. Таблица 3. Общая численность (экз. $\mathrm{M}^{-2}$ ) и процентное соотношение (в скобках) отрядов двупарноногих многоножек.

\begin{tabular}{|l|c|c|c|c|c|c|c|}
\hline Orders & D-1600* & D-1800 & C-2000 & D-2150 & C-2340 & D-2350 & R-2370 \\
\hline Chordeumatida & - & $5(2.9)$ & - & $3.5(2.5)$ & $28(15.7)$ & $14.5(3.6)$ & $11(3.1)$ \\
Julida & $130.7(32)$ & $130.5(75)$ & $24(10.1)$ & $18(12.7)$ & $61(34.3)$ & $188(46.2)$ & $59(16.6)$ \\
Platydesmida & - & $1.5(0.9)$ & - & $5(3.5)$ & $6(3.4)$ & $0.5(0.1)$ & - \\
Polydesmida & $277.3(68)$ & $36(20.7)$ & $204(85.5)$ & $89.5(63)$ & $83(46.6)$ & $203.5(50)$ & $270(75.8)$ \\
Spirostreptida & - & - & $2.5(1)$ & - & - & - & - \\
Glomeridae & - & - & $2(0.8)$ & - & - & - & - \\
Polyxenida & - & - & $4(1.7)$ & $4(2.8)$ & - & - & $16(4.5)$ \\
Siphonophorida & - & $1(0.6)$ & $2(0.8)$ & $20(14.1)$ & - & - & - \\
Sphaerotherida & - & - & - & $2(1.4)$ & - & $0.5(0.1)$ & - \\
\hline Total & 408.0 & 174.0 & 238.5 & 142.0 & 178.0 & 407.0 & 356.0 \\
\hline
\end{tabular}

na density). A total of twelve insect orders were found though Coleoptera and Diptera larvae were most numerous. The rove beetles of subfamilies Aleocharinae and Oxytelinae were the most abundant beetles (Table 4). The density of Staphylinidae was higher in peat soils (30\% of all beetles), as well as of Tenebrionidae. On the contrary, scarab beetles reached maximum density in mineral soils of deciduous forests. Carabidae had low abundance at all sites except deciduous forests at 2160 and $2350 \mathrm{~m}$ a.s.1.

The density of Diptera larvae was greatest in soil of deciduous forest at $2350 \mathrm{~m}$ a.s.l. due to the great abundance of predatory Tabanidae (Table 5). In the peat soils of coniferous forests the density of all dipteran larvae was low. The reasons for this pattern are not clear.

Termites were not taken into account in this study, but it should be noted that Isoptera were a common group of soil animals at altitudes below $2000 \mathrm{~m}$ a.s.l. and were absent at sites above this level.

Biodiversity of soil macrofauna. Considering difficulties with taxonomic identification of tropical soil invertebrates down to species level, the estimation of the diversity of soil macrofauna was conducted using "morphospecies" (i.e. a group of invertebrates that differs in morphology from all other groups). This approach was proven as a useful tool in environmental monitoring and conservation studies [Kremen et al., 1993; Oliver, Beattie, 1996; Derraik et al., 2002].

The number of morphospecies found at particular sites varied from 102 to 187 with a total diversity of more than 510 morphospecies (Fig. 6). Using the abundance-based estimator Chao 1 [Chao, 1984], the predicted diversity for all sites is $1024 \pm 82$ morphospecies. This suggests that at least $50 \%$ of species of soil macrofauna remain unregistered. Nevertheless, the recorded level of taxonomic diversity exceeded respective value in a lowland monsoon semi-deciduous tropical forests of southern Vietnam (Chao 1 estimator based on 67 samples $=626 \pm 27$ morphospecies) [Anichkin,
2011], as well as the diversity of soil invertebrates in temperate woodlands [Striganova, Poryadina, 2005].

Vertical distribution of soil invertebrates. Soil invertebrates occurred throughout the soil profile to a depth of $20 \mathrm{~cm}$ in mineral soils and to $30 \mathrm{~cm}$ in peat soils (Fig. 7). The abundance of soil invertebrates reached maximum in the upper 2-cm layer of mineral soils $(58 \%$ of total abundance in deciduous forests, except site R-2370) and upper FH horizons of litter in coniferous forests and the deciduous forest at $2370 \mathrm{~m}$ a.s.1. (ca. $50 \%$ of total abundance). The biomass had the highest values in the layer of $2-10 \mathrm{~cm}$. The differ-

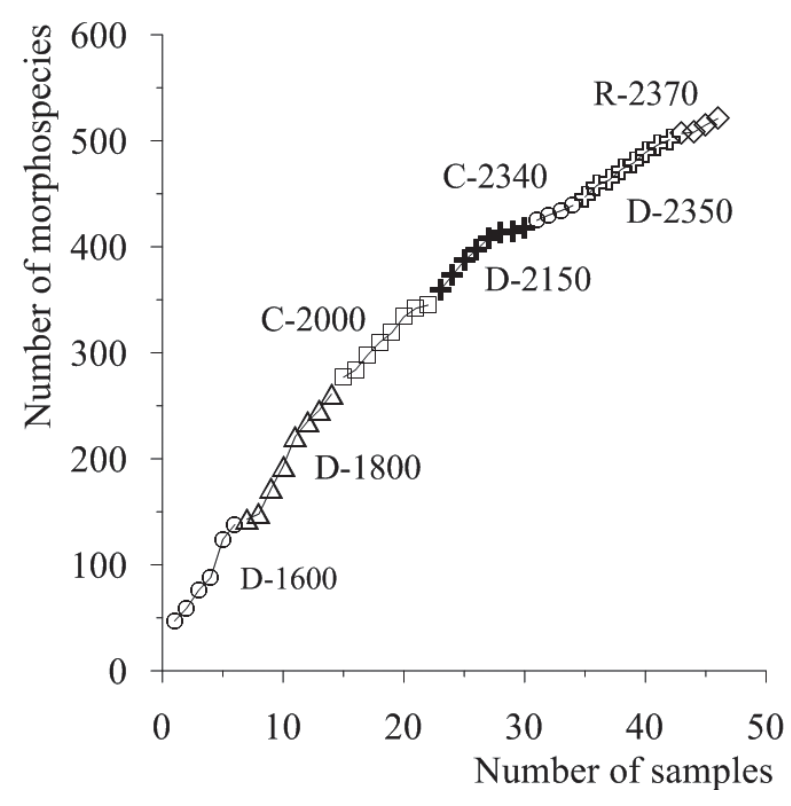

Fig. 6. The species-accumulation curve for all samples (collector method). The curve is not asymptotic indicating that new species would be found by additional sampling at each site.

Рис. 6. Кривая накопления видов в зависимости от числа отобранных проб. Кривая показывает, что при увеличении количества проб возможно обнаружение новых видов. 
Table 4. The density (ind. $\mathrm{m}^{-2}$ ) of the beetle families and subfamilies. Таблица 4. Численность (экз. м $^{-2}$ ) отдельных семейств и подсемейств жуков.

\begin{tabular}{|c|c|c|c|c|c|c|c|}
\hline Groups & D-1600 & D-1800 & $\mathrm{C}-2000$ & D-2150 & C-2340 & D-2350 & R-2370 \\
\hline Carabidae & 32.0 & 3.0 & 2.5 & 12.5 & 1.0 & 48.5 & 1.0 \\
\hline Ptiliidae & - & 3.0 & - & 6.5 & 9.0 & 6.5 & 7.0 \\
\hline Staphylinidae & 29.3 & 65.0 & 137.0 & 66.0 & 142.0 & 79.5 & 74.0 \\
\hline Aleocharinae & 10.7 & 18.5 & 96.0 & 17.5 & 34.0 & 37.5 & 19.0 \\
\hline Euaesthetinae & - & - & 4.5 & 0.5 & 16.0 & - & 15.0 \\
\hline Oxytelinae & 2.7 & 12.5 & 15.0 & - & 55.0 & 8.5 & 17.0 \\
\hline Paederinae & - & 3.0 & - & 2.0 & 2.0 & 3.0 & - \\
\hline Staphylininae & 8.0 & 10.5 & 8.5 & 6.0 & 3.0 & 8.0 & 4.0 \\
\hline Steninae & - & - & - & - & - & - & 9.0 \\
\hline Tachyporinae & 2.7 & 4.0 & - & 2.5 & - & - & - \\
\hline Pselaphinae & 2.7 & 8.5 & 4.0 & 25.5 & 8.0 & 16.5 & 5.0 \\
\hline Scaphidiinae & - & 5.5 & 0.5 & - & - & - & - \\
\hline Dasycerinae & - & - & - & - & - & 0.5 & - \\
\hline Scydmaeninae & - & - & - & - & - & - & - \\
\hline Scarabaeidae & 32.0 & 32.0 & 8.0 & 18.5 & 5.0 & 6.0 & - \\
\hline Scarabaeidae (adults) & 10.7 & - & 4.0 & 0.5 & 5.0 & 6.0 & - \\
\hline Scarabaeidae (juveniles) & 21.3 & 32.0 & 4.0 & 18.0 & - & - & - \\
\hline Lucanidae & 2.7 & - & - & - & - & - & - \\
\hline Elateridae & 34.7 & 18.5 & 56.0 & 28.0 & $2-$ & 44.5 & 44.0 \\
\hline Elateridae (adults) & 5.3 & 2.0 & - & - & - & 0.5 & - \\
\hline Elateridae (juveniles) & 29.3 & 16.5 & 56.0 & 28.0 & $2-$ & 44.0 & 44.0 \\
\hline Nitidulidae & - & - & 0.5 & 4.0 & 1.0 & - & - \\
\hline Tenebrionidae & 10.7 & 34.0 & 55.5 & 24.0 & 47.0 & 26.0 & 18.0 \\
\hline Tenebrionidae (adults) & 5.3 & 17.5 & 26.0 & 0.5 & 15.0 & 4.0 & 18.0 \\
\hline Tenebrionidae (juveniles) & 5.3 & 16.5 & 29.5 & 23.5 & 32.0 & 22.0 & - \\
\hline Chrysomelidae & 8.0 & 0.5 & 2.0 & - & - & 6.0 & 1.0 \\
\hline Chrysomelidae (adults) & 2.7 & 0.5 & 2.0 & - & - & - & 1.0 \\
\hline Chrysomelidae (juveniles) & 5.3 & - & - & - & - & 6.0 & - \\
\hline Anthribidae & - & - & - & 0.5 & - & - & - \\
\hline Curculionidae & 21.3 & 11.0 & 9.5 & 6.0 & 7.0 & 8.5 & 42.0 \\
\hline Curculionidae (adults) & 5.3 & 6.5 & 9.5 & 6.0 & 7.0 & 6.5 & 42.0 \\
\hline Curculionidae (juveniles) & 16.0 & 4.5 & - & - & - & 2.0 & - \\
\hline Scolytinae & - & 0.5 & - & - & - & 6.0 & - \\
\hline Anthicidae & - & 2.0 & - & - & - & 6.5 & - \\
\hline Cantharidae & - & - & 2.0 & - & - & - & - \\
\hline Clambidae & - & 2.0 & 2.0 & - & 1.0 & 13.5 & - \\
\hline Corylophidae & - & 4.5 & 2.0 & 1.0 & - & 2.0 & - \\
\hline Cryptophagidae & - & - & - & - & - & 0.5 & 3.0 \\
\hline Endomychidae & - & - & - & - & - & 1.0 & - \\
\hline Histeridae & - & - & 0.5 & 0.5 & - & 1.0 & - \\
\hline Hydrophilidae & - & 3.0 & 5.5 & - & 1.0 & - & - \\
\hline Latridiidae & - & 0.5 & - & - & - & - & - \\
\hline Leiodidae & 5.3 & 23.5 & 18.5 & 6.0 & - & 5.5 & 4.0 \\
\hline Limnichidae & - & - & 2.0 & - & - & - & - \\
\hline Melandryidae & - & 0.5 & - & 0.5 & - & 1.0 & 6.0 \\
\hline Scirtidae & - & 2.0 & - & - & - & - & - \\
\hline Scraptiidae & - & 2.0 & 4.5 & - & 4.0 & 2.0 & - \\
\hline Other Coleoptera (adults) & 2.7 & 5.5 & 3.0 & 4.0 & 13.0 & 5.5 & 6.0 \\
\hline Other Coleoptera (juveniles) & 50.7 & 44.5 & 33.0 & 32.0 & 82.0 & 40.5 & 29.0 \\
\hline Other Coleoptera (pupa) & 13.3 & 4.5 & 4.0 & 6.0 & 28.0 & 10.5 & 4.0 \\
\hline Total & 242.7 & 262.0 & 348.0 & 216.0 & 365.0 & 321.0 & 239.0 \\
\hline
\end{tabular}


Table 5. The density (ind. $\mathrm{m}^{-2}$ ) of Diptera larvae in soils of investigated sites. Таблица 5. Численность (экз. м $^{-2}$ ) личинок мух в почве исследованных площадках.

\begin{tabular}{|l|c|c|c|c|c|c|c|}
\hline Groups & D-1600* & D-1800 & C-2000 & D-2150 & C-2340 & D-2350 & R-2370 \\
\hline Nematocera & 16 & 13.5 & - & 9 & 9 & 13.5 & 4 \\
Tipulidae & 8 & - & - & - & - & - & - \\
Bibionidae & 2.7 & 5 & - & 4 & - & - & - \\
Cecidomyidae & 2.7 & - & - & - & - & 0.5 & - \\
Ceratopogonidae & - & 1 & - & 2.5 & - & 5 & - \\
Chironomidae & 2.7 & 6 & - & - & - & 6 & 4 \\
Limoniidae & - & - & - & - & 8 & - & - \\
Other Nematocera & - & 1.5 & - & 2.5 & 1 & 2 & - \\
Brachicera & 8 & 7.5 & 18.5 & 10.5 & 8 & 58 & 20 \\
Tabanidae & 2.7 & 2 & 12 & 8.5 & - & 46 & 8 \\
Asilidae & - & - & - & 2 & - & - & - \\
Syrphidae & - & 1 & - & - & - & - & - \\
Muscidae & - & - & 6 & - & 4 & 3.5 & - \\
Anthomiidae & - & - & - & - & 4 & - & 4 \\
Empididae & 2.7 & - & - & - & - & 2 & 4 \\
Drosophilidae & - & - & - & - & - & 3.5 & - \\
Lauxaniidae & - & 4.5 & - & - & - & 1 & - \\
Other Brachicera & 2.7 & - & 0.5 & - & - & 2 & 4 \\
\hline Total & 24 & 21 & 18.5 & 19.5 & 17 & 71.5 & 24 \\
\hline
\end{tabular}

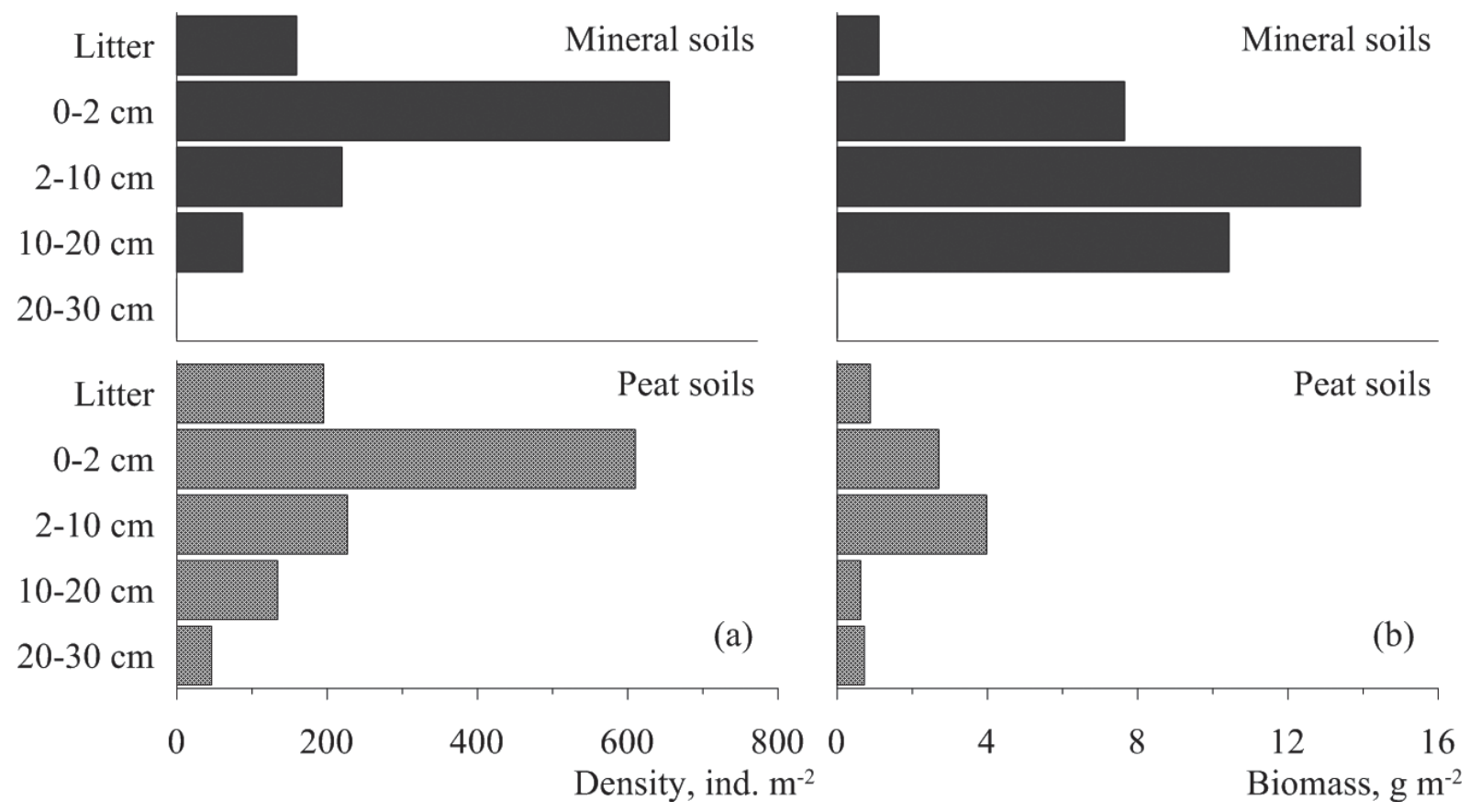

Fig. 7. Vertical distribution of abundance (a) and biomass (b) of soil invertebrates in mineral and peat soils.

Рис. 7. Вертикальное распределение численности (а) и биомассы (b) почвенных беспозвоночных в минеральной и торфяной почве.

ence is related to the differences of the size of animals inhabiting different soil layers. Most animals of top layers were typical stratobionts or epigeobionts with a body length of $1-5 \mathrm{~mm}$. In deeper horizons of soils (especially of mineral soils), populations of soil animals were composed of larger invertebrates (geobionts) like beetle larvae (Scarabaeidae, Elateridae, Chrysomelidae) or earthworms (Lumbricinae). In soft organic soils (peat soils) the distribution of total biomass through soil profile was somewhat more uniform.

Trophic structure. Detritivores formed the bulk of soil invertebrates in all studied sites (Fig. 8). There 


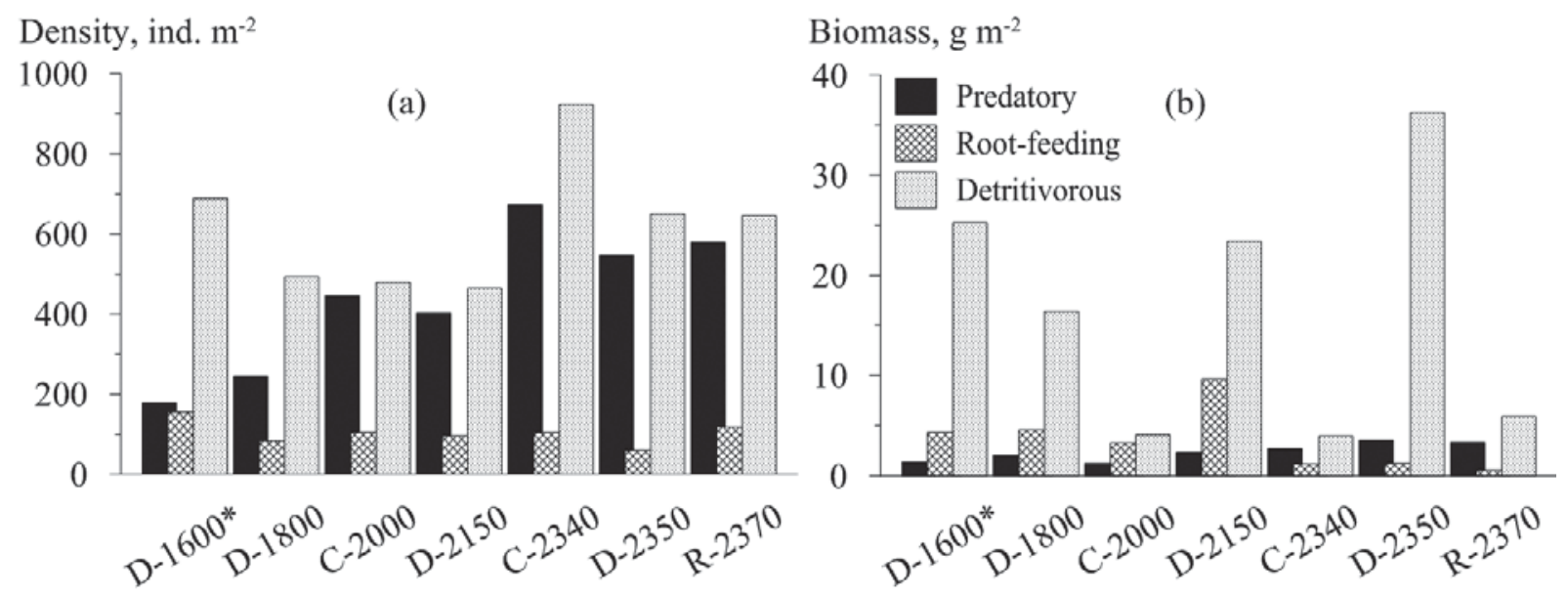

Fig. 8. The density (a) and biomass (b) of main trophic groups of soil macrofauna.

Рис. 8. Численность (а) и биомасса (b) основных трофических групп почвенной.
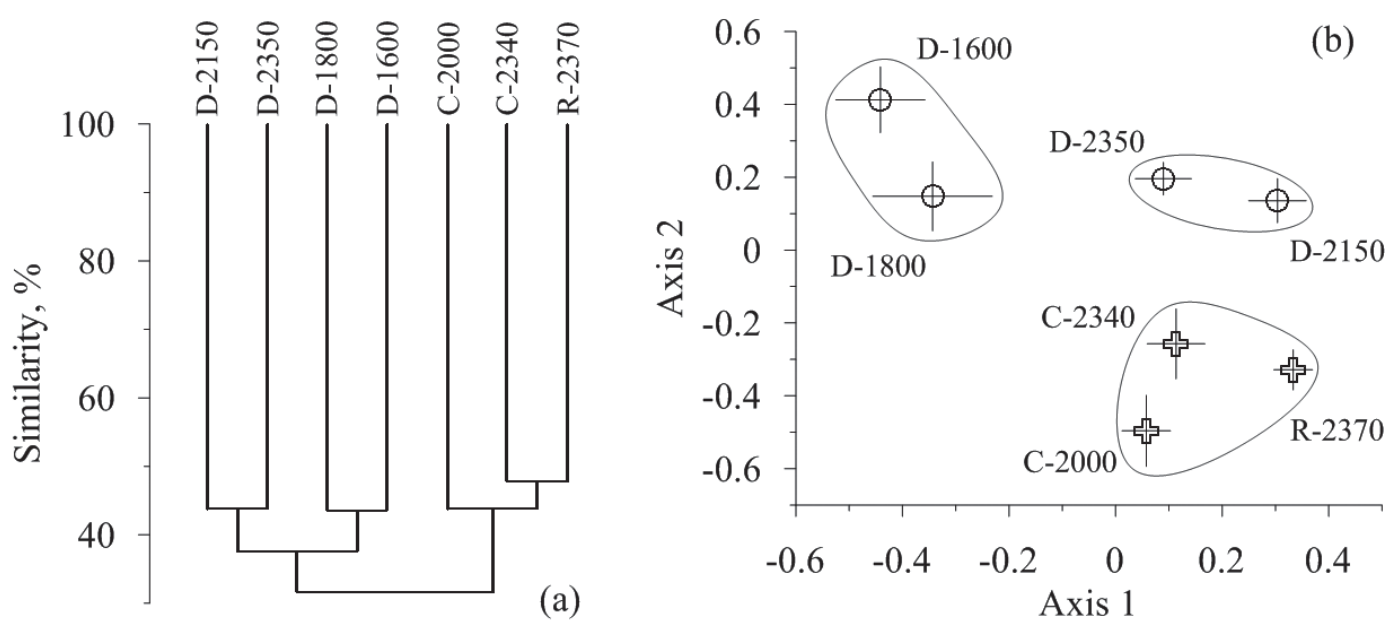

Fig. 9. (a) Dendrogram based on average linkage of Bray-Curtis similarity matrix of soil macrofauna communities at seven sites and (b) Results of non-metric multidimensional scaling ordination of soil invertebrates communities (each point shows the centroid of samples from each site \pm standard error of mean).

Рис. 9. (а) Дендрограмма сходства сообществ почвенных беспозвоночных семи площадок и (b) результаты немпараметрического многомерного шкалирования сообществ педобионтов разных площадок (каждая точка показывает центроид проб каждой площадки \pm стандартная ошибка средней).

were however clear differences in the relative biomass of trophic groups in two soil types. The fraction of detritivores in coniferous forests did not exceed $60 \%$, whereas the biomass of predators reached 34\% (in deciduous forests it did not exceed $8 \%$ ). Noteworthy, the ratio of trophic groups in the deciduous forest at $2370 \mathrm{~m}$ a.s.l. was the same as in coniferous forests. Thus, there was a general pattern of increased fraction of predators and decreased proportion of detritivores in peat soils. The activity of detritivores depends on chemical properties of leaf litter [Nicolai, 1988; Tian et al., 1993; Zou, 1993; Wardle, 2004]. We can therefore suggest lower nutritive value of pine litter for soil invertebrates. In addition, leaves of rhododendrons have toxic properties [Yang et al., 2011]. These features of leaf litter at sites with peat soils, combined with low
$\mathrm{pH}$ level, may lead to the decrease in the role of saprophagous invertebrates in decomposition of litter material and to an increased role of fungal decomposers [Kozlovskaya, 1976].

Specificity of local communities. Bray-Curtis similarity index identified two main clusters: communities of mineral soils and those of peat soils (Fig. 9a). The highest similarity (ca. 50\%) was observed between coniferous forests at $2340 \mathrm{~m}$ a.s.1. and deciduous forests with rhododendron. The ordination of samples confirmed the specificity of local soil macrofauna communities. The differences among samples within each site were considerably lower than among sites. Non-metric multidimensional scaling produced two main axes; the first axis separated deciduous forests situated below and above $2000 \mathrm{~m}$ a.s.1 The second axis separated 
communities of soil invertebrates in peat soils and mineral soils (Fig. 9b).

\section{Conclusion}

The distribution of soil invertebrates in studied mountain forests suggests that the main factors controlling the abundance of soil macrofauna are related to the quantity of plant litter as well as the abundance of termites. It seems plausible that the increase in density of invertebrates with altitude results from the replacement of termites by other detritivorous groups of soil animals which form an analogous functional assembly of destructors of dead organic matter. On the other hand, the total biomass of soil invertebrates is determined primarily by the quality (nutritive value) of leaf litter and soil properties (physical properties, $\mathrm{pH}$, etc).

Acknowledgements.

We would like to thank S.I. Golovatch, V.B. Semenov, O.A. Starodubtseva, M.G. Krivosheina, D.N. Fedorenko, D.V. Logunov and Yu.M. Marusik for help in taxa identifications and the administration of Ngok Linh Nature Reserve for providing permission and facilities for fieldwork. We thank the staff of RussianVietnamese Tropical Centre, especially A.N. Kuznetsov and S.P. Kuznetsova for support in realization of this research. Finally we thank B.R. Striganova for valuable advice and remarks.

\section{References}

Anichkin A.E. 2011. [Soil macrofauna: structure and seasonal dynamics] // Struktura i funktsii pochvennogo naseleniya tropicheskogo mussonnogo lesa (natsional'niy park Cat Tien, Yuzhniy Vietnam). Moscow: KMK. P.44-75 [in Russian].

Anichkin A.E., Belyaeva N.V., Dovgobrod Iu.G., Shveenkova Ju.B., Tiunov A.V. 2007. Soil microarthropods and macrofauna in monsoon tropical forests of Cat Tien and Bi Dup-Nui Ba National Parks, Southern Vietnam // Biology Bulletin. Vol.34. No.5. P. 498-506.

Chao A. 1984. Non-parametric estimation of the number of classes in a population // Scandinavian J. Statistics. Vol.11. P.265270 .

Collins N.M. 1980. The distribution of soil macrofauna on the West Ridge of Gunung (Mount) Mulu, Sarawak // Oecologia. Vol.44. P.263-275.

Derraik J.G.B., Closs G.P., Dickinson K.J.M., Sirvid P., Barrat B.I. P., Patrick B.H. 2002. Arthropod morphospecies versus taxonomic species: a case study with Araneae, Coleoptera, and Lepidoptera // Conservation Biology. Vol.16. No.4. P.10151023.
Edwards C.A., Bohlen P.J. 1996. Biology and ecology of earthworms. 3rd ed. London, UK: Chapman \& Hall.

Ghilarov M.S. 1975. [Methods of Soil Zoology Research.] Moscow: Nauka. 281 p. [in Russian].

Huhta V., Hyvönen R., Koskenniemi A., Kaasalainen P., Sulander M. 1986. Response of soil fauna to fertilization and manipulation of $\mathrm{pH}$ in coniferous forests // Acta for. Fenn. Vol.195. P.1-30.

Kozlovskaya L.S. 1976. [The role of invertebrates in transformation of peat soil organic matter.] Leningrad: Nauka. 211 p. [in Russian].

Kremen C., Colwell R.K., Erwin R.K., Murphy D.D., Noss R.F., Sanjayan M.A. 1993. Terrestrial arthropod assemblages: their use in conservation planning // Conservation Biology. Vol.7. P.796-808.

Krivolutskii D.A., Huynh Thi Kim Hoi, Usachev V.L. 1994. [Ecology of the Soil Fauna in Mountain Ecosystems of Northern Vietnam] // Ekologiya. Vol.4. P.284-290 [in Russian].

Leakey R.J., Proctor J. 1987. Invertebrates in the litter and soil at a range of altitudes on Gunung Silam, a small ultrabasic mountain in Sabah // J. Trop. Ecol. Vol.3. P.119-129.

Nicolai V. 1988. Phenolic and mineral contents of leaves influences decomposition in European forests systems // Oecologia. Vol.75. P.575-579.

Oliver I., Beattie A.J. 1996. Invertebrate morphospecies as surrogates for species: a case study // Conservation Biology. Vol.10. P.99-109.

Persson T., Baath E., Clarholm M., Lundkvist H., Soderstrom E., Sohlenius B. 1980. Trophic structure, biomass dynamics and carbon metabolism of soil organisms in a Scots pine forest // $\mathrm{T}$. Persson (ed.). Structure and function of northern coniferous forests. An ecosystem study. Ecol. Bull., Stockholm. P.419459.

R Development Core Team. 2009. R: A language and environment for statistical computing. R Foundation for Statistical Computing, Vienna, Austria. ISBN 3-900051-07-0, URL http://www.Rproject.org.

Sharova I.Ch. 1981. [Life forms of ground beetles (Coleoptera, Carabidae).] Moscow: Nauka Publ. 283 p. [in Russian]

Sorensen L.L. 2004. Composition and diversity of the spider fauna in the canopy of a montane forest in Tanzania // Biodiversity and Conservation. Vol.13. P.437-452.

Striganova B.R., Poryadina N.M. 2005. [Soil animal population in boreal forests of West-Siberian Plain.] İoscow: Ề̂E Scientific Press Ltd. 234 p. [in Russian].

Tian G., Brussaard L., Kang,B.T. 1993. Biological effects of plant residues with contrasting chemical compositions under humid tropical conditions: effects on soil fauna // Soil Biology and Biochemistry. Vol.25. P.731-737.

Wardle D.A., Bardgett R., Klironomos J., Setala H., Van der Putten W.H., Wall D. 2004. Ecological linkages between aboveground and belowground biota // Science. Vol.304. P.1629-1633.

Yang K., Zhou Y.X., Wang C.F., Du S.S., Deng Z.W., Liu Q.Z., Liu Z.L. 2011. Toxicity of Rhododendron anthopogonoides essential oil and its constituent compounds towards Sitophilus zeamais // Molecules. Vol.16. P.7320-7330.

Zou X. 1993. Species effect on earthworm density in tropical tree plantations in Hawaii // Biology and Fertility of Soils. Vol.15. P.35-38. 